\title{
Operationality of concepts in Heideggerian phenomenological investigation: epistemological reflection on Nursing
}

\author{
Operacionalidade de conceitos em investigação fenomenológica heideggeriana: reflexão epistemológica na enfermagem
} Operación de los conceptos en investigación fenomenológica heideggeriana: reflexión epistemológica en la enfermería

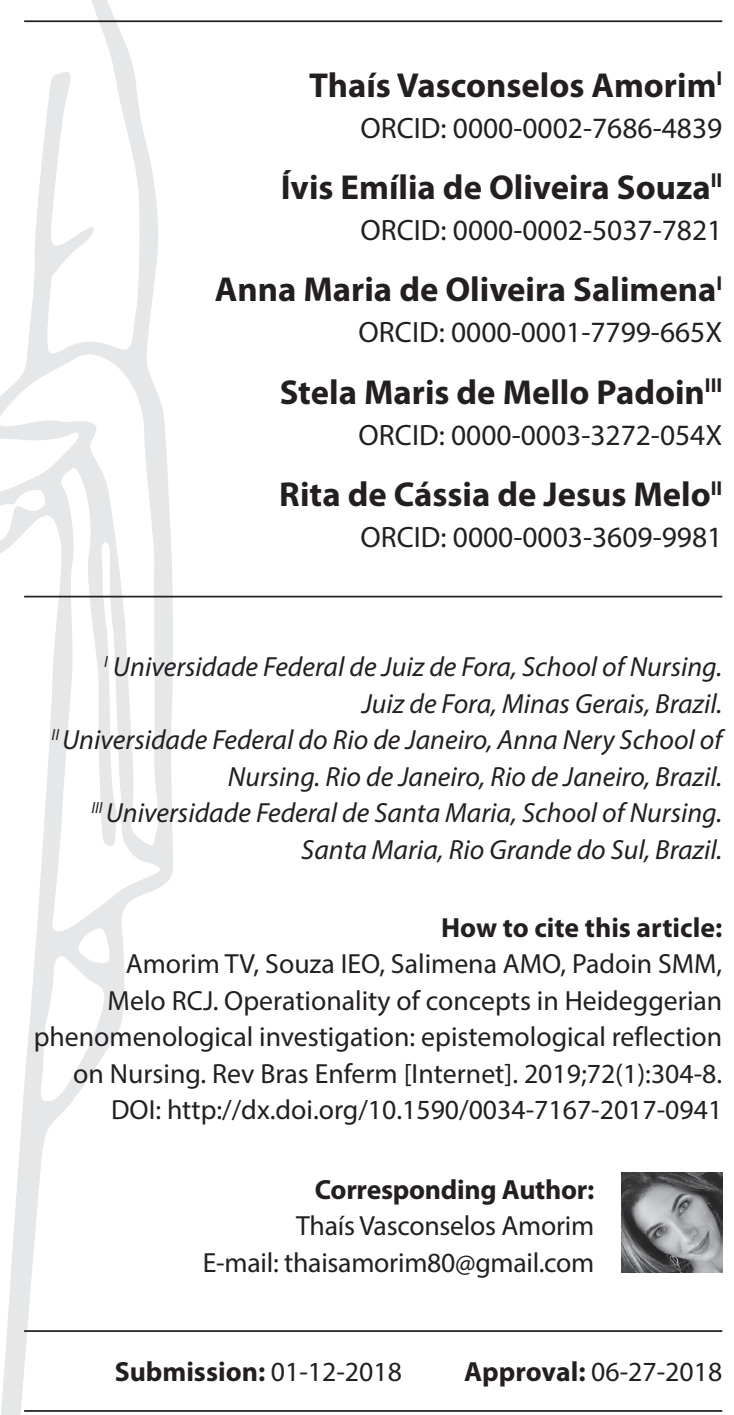

Submission: $01-12-2018$

Approval: 06-27-2018

\section{ABSTRACT}

Objective: To describe the investigative path of analysis and the operationality of concepts based on Martin Heidegger's theoretical and philosophical framework. Method: Theoretical reflection on the phenomenon of pregnancy in a woman with heart disease. Results: Stages of the investigative movement were evidenced based on the pre-reflection related to the object of study and to the search for the phenomenal meaning, using the existential and analytical Hermeneutics as the approach and resulting in the reach of the phenomenal totality. Conclusion: The worldview of the researcher, who considered the subjectivities of the person in a health or disease situation, favored the announcement of the referential by the object of study. Knowledge production in the light of Martin Heidegger's phenomenology unveiled phenomena lived and experienced in the Health and Nursing field, provided of epistemological rigor that demanded appropriation of concepts inherent to the existential analytics.

Descriptors: Qualitative Research; Methods; Philosophy; Nursing, Woman's Health.

\section{RESUMO}

Objetivo: Descrever o caminho investigativo de análise e a operacionalidade de conceitos sustentados no referencial teórico-filosófico e metodológico de Martin Heidegger. Método: Reflexão teórica do fenômeno de gestar sendo mulher portadora de cardiopatia. Resultados: Evidenciaram-se as etapas do movimento de investigação a partir do pré-reflexivo relativo ao objeto de estudo e da busca do sentido fenomenal na direção da hermenêutica como analítica existencial, culminando no alcance da totalidade fenomênica. Conclusão: A visão de mundo do investigador, que considerou as subjetividades da pessoa em situação de saúde ou doença, favoreceu que o objeto de estudo anunciasse o referencial. A produção de conhecimento à luz da fenomenologia de Martin Heidegger desvelou fenômenos vividos e vivenciados no campo da saúde e da enfermagem, mediante rigor epistemológico que exigiu apropriação de conceitos inerentes à analítica existencial.

Descritores: Pesquisa Qualitativa; Métodos; Filosofia; Enfermagem; Saúde da Mulher.

\section{RESUMEN}

Objetivo: Describir el camino investigativo de análisis y la operación de los conceptos sostenidos en el referencial teórico-filosófico y metodológico de Martin Heidegger. Método: Reflexión teórica del fenómeno de gestar siendo mujer portadora de cardiopatía. Resultados: Se evidenciaron las etapas del movimiento de investigación a partir del pre-reflexivo relativo al objeto de estudio y de la búsqueda del sentido fenomenal hacia la hermenéutica como analítica existencial, culminando en el alcance de la totalidad fenoménica. Conclusión: La visión de mundo del investigador, que consideró las subjetividades de la persona en situación de salud o enfermedad, favoreció que el objeto de estudio anunciara el referencial. La producción de conocimiento a la luz de la fenomenología de Martin Heidegger desveló fenómenos vividos y vivenciados en el campo de la salud y de la enfermería, mediante rigor epistemológico que exigió apropiación de conceptos inherentes a la analítica existencial.

Descriptores: Investigación Cualitativa; Métodos; Filosofía; Enfermería; Salud de la Mujer. 


\section{INTRODUCTION}

Health care to the individual, family and collectivity that covers the totality, responsible for characterizing the being of the human, is overlapped in plural dimensions. In these dimensions, according to the theoretical framework of the Heideggerian phenomenology, it is crucial to distinguish the technical making of actions and facts - ontical domain -, to aim the subjective dimension, when one is concerned with the human being, assuming the ontical domain, which is from the phenomenon ${ }^{(1)}$. With this theoretical direction, the health care will be produced according to the manner of being with the other, allowing welcoming and bonding so that this human, subject of care actions, can make his/her choices and also perform his/her freedom with responsibility ${ }^{(2)}$.

With this perspective, studies on nursing are developed under the paradigms of the exact and natural or social and human sciences, approaching philosophical, theoretical and methodological referential frameworks that assist in the search for impacting results in the professional practice of nurses and other members of the healthcare team ${ }^{(3)}$.

Taking into consideration the research of qualitative approach guided by philosophical and hermeneutic analytical paths, it is worth highlighting the use of phenomenology as method that is developed through scientific rigor on search and apprehension of phenomena inherent to the healthcare process. These phenomena, that are immanent of experiences and meanings lived in the several contexts of a human being's life and world, will be showed through themselves, in what they are and how they are ${ }^{(4)}$.

In this sense, investigations on Nursing have been using the phenomenological framework to understand the Being (italicized expressions are from Martin Heidegger's theoretical framework) of those who propose themselves in the provision of care, whether in health promotion with the aim of remaining healthy or in situations of diseases, with their being-ill, using expressively Heidegger's thinking. Nurses, broadening their worldview, have been acting on the epistemological construction that results from the experiences, livings and problematics in their labor everyday life, encompassing themes focused on health of the mind, the worker, the adults, the old person, the child, the adolescent, and the woman, unveiling phenomena in their several facets ${ }^{(3)}$.

In women's health area the situation evidenced the most is that for heart diseases, which compose the epidemiological framework of maternal morbidity and mortality due to indirect obstetric causes, that remains high regardless of the political and programmatic advances ${ }^{(5)}$. This is the focus of Brazilian guidelines, attentive to physiopathological aspects, considered a priority in the surveillance of the entire pregnancy and postpartum cycle and constant fetal monitoring, due to the wider risk of congenital heart dysfunction. Therefore, their recommendation is that women with diagnosed heart injuries must be previously oriented about the risks during pregnancy ${ }^{(6)}$.

However, in the labor everyday life of health professionals focused on women with heart diseases, the discussion of the politics around the sexual and reproductive rights is established, including the woman's desire of getting pregnant as a human right to be respected and ensured by government laws, regardless of the physiopathological aspects and recommendations structured in guidelines ${ }^{(6)}$.
The immersion in this everyday life, with attentive observation to the other's subjectivity and beyond the biological optics, attracted the attention of women with heart diseases when the desire of getting pregnant was mentioned. During the nursing care they expressed their fears in relation to their own health and expectations for her family and medical team. Therefore, however much the technical aspects for management of clinical situations have advanced, those of subjective nature remain veiled, obscure and little or not always prioritized by the care methodologies. That also remains, paradoxically, in the discursive maintenance of humanization and factual execution of biomedicalization.

From the thesis "Gestate-when-having-heart-diseases: contributions to the woman's health care (Gestar sendo-portadorade-cardiopatia: contribuições para o cuidado em saúde da mulher)" defended in the Graduate Program in Nursing of the Anna Nery School of Nursing at the Federal University of Rio de Janeiro, the need of considering "who" is this woman that impregnates whenhaving-heart-diseases was elected to unveil this phenomenon in its essence. It became relevant to investigate the meaning of the experience of and the lived in gestating for the woman with heart disease, since these two aspects have already been understood by science in a explicative and causal mode, in conformity with the quantitative approach. In this direction, the philosophical and methodological framework of Martin Heidegger's phenomenology was configured as epistemologically appropriate ${ }^{(5)}$.

The priority was to conduct a survey of the current knowledge state about the theme on high-risk pregnancy due to heart disease, considering its implications for health and nursing care. The evidenced was that the guidance for professional practice results from robust scientific production around guidelines, technical manuals and studies of qualitative approach that lead to the biological know-how. The need of contemplating investigations of qualitative approach that prioritize the subjective dimension of this phenomenon was noticed ${ }^{(7)}$.

\section{OBJECTIVE}

To describe the investigative path of analysis and the operationality of concepts based on Martin Heidegger's theoretical and philosophical framework.

\section{Investigative path: phenomenology as school of thought}

The phenomenology, an emerging philosophical school at the end of the $19^{\text {th }}$ and beginning of the $20^{\text {th }}$ century as counter-thought to positivism and empiricism, materializes in opposition to Descartes and Spinoza's axiomatic ideas. It criticizes the dichotomy between human subjectivity and objectivity for considering them as inseverable. Its concern was focused on the explanation and description of the essential structures in certain experience that emerges from conscientious acts ${ }^{(8)}$.

Among philosophers of this time there is Martin Heidegger, who elected as guidance for his thinking the theory of the Being, as the Aristotle's Being, and the phenomenological method of Husserl, of whom he became acolyte in 1919. He assumed a different behavior from his professor with regard to the transcendentalism of ideas, intending to terminate it from the method 
itself. Heidegger's reflection is centered on the philosophy that has as theme the Being according to the Western philosophy. Thus, the continuous interrogation is constituted and seeks to understand the object that is interrogated and directs its steps and movements toward the "issue about the Being [...] in the sense of what remains fundamentally veiled"(8).

Martin Heidegger's thought considers the description of phenomena that contemplate the Being based on the issues directed to it and of what is preserved veiled. For thus, he uses the premise that, what is able to be manifested by itself has the possibility of being hidden in the movement of the being of the entity in its Being-in-the-world everyday life ${ }^{(9)}$.

In Being and Time, his main work published in 1927, the philosopher was dedicated in showing, preliminarily, that despite universal and evident, the concept of Being is indefinite, being necessary its interrogation through investigation that seeks the phenomenon of interest based on its ontical dimension (entity) considering the access to the ontological dimension (Being-there). For that, the author considers as starting point the concrete reality, which is factually given, historic and temporarily susceptible to comprehension.

Thus, Heidegger takes the phenomenology in its methodic possibility based on the "how we get in touch with things", in an interpretative movement named "hermeneutics of facticity", able of announcing "the being of the entity so that the own Being comes to appearance "(9).

The method in Heidegger is not disassociated of its philosophical reflection, but is revealed through it. That is why, in the first instance, there is the need for the interrogation about the sense of the Being, in the phenomenon situated and of interest. As this phenomenon is questioned, the Being-researcher opens the possibility of the investigative path.

Thus, considering the research that caused this theoretical reflection, the experiences in world of nursing care together with women with heart diseases and the previous position, which is from the scientific tradition, according to the Heideggerian philosophy, are conjectured in the stage of pre-reflection as thought that involved the issue of the thesis. However, in the search for the phenomenon, the suspension of these ideas was considered, a priori, attentively observing the searched for, the thing itself, so in fact the conduction of the study could be characterized in the phenomenological perspective.

The appreciation of the possibilities in impregnating when having heart diseases culminated in an authentic interest of bending over this phenomenon that emerged little by little as possibility of illumination and unveiling, based on the sphere of facts (ontical) toward that of senses (ontological).

Parallel to this vision, it is incited to "previously ensure a proper way of accessing the entity"(9), which in this research is what shelters the Being-woman with heart diseases that could mean in the future the experience and the lived of her pregnancy. The access to it involved, in addition to issues related to the ontical sphere, the pre-occupation in Being-with her in an authentic mode, aiming at favoring the original donation of meanings that constitute the phenomenon of interest.

For that, the interview was used in the phenomenological modality mediated by the empathic attitude as means for the opening of possibilities for women's showing-itself, favoring the obtainment of facts of their clinical and obstetric sociocultural profile that, together with their history, were constituted in the historiography that reveals data on the $w h o^{(4)}$.

Considering the issue on the opening of the meeting, the questioning was presented, methodically, in three domains, in which the entity, women with heart diseases that experienced or experience pregnancy, was interrogated; the Being-woman that gestated having-heart-diseases was questioned and expressed the meanings of experiencing/have experienced this pregnancy, seeking the sense of the Being-woman-that-gestated-having-heart-diseases.

After investigating the object in the light of tradition and of what it reveals as previous investigation, which is from science, the Soil of Tradition was composed from the facts already stated, evidenced and published about the high-risk pregnancy due to heart disease. After establishing this basis, the phenomenon experience of gestating-when-having-heart-diseases - in study was searched.

\section{Building the episteme: operationality of Heideggerian concepts}

The attentive search for clues of the who was shown through the said and unsaid, preserving the phenomenological attitude. It was possible to ontically assess the who of women that announced themselves since contact by phone and that signified in the report their possibilities of Being-there, allowing the construction of their historiography and historicity, which reveals data of the who sustained in their history and their lime lived. This movement intended the visualization and comprehension of the ontical-ontological bridge, which allowed the opening of horizons for the other methodical domains.

Exhaustive and attentive reading and listening of the reports were important, in a movement of going to the things themselves, of what was shown, in the reality it was shown being what it is, the essence. It is emphasized the challenging, insistent and permanent exercise of rethinking and considering at all times the suspension of presuppositions that emerge from the healthcare everyday life of nurses together with women who have heart diseases. This necessary phenomenological reduction inaugurated the scientific rigor in the analytical stage, because it was attentive to the relation subject and subject based on the experience lived aimed at understanding and describing it, since the tradition had already assessed it.

The phenomenological reduction allowed the emergence of essences by distinction of occasional meanings of essential structures. The latter, perceived by the objectivity of subjectivities, in the first instance by intuition, based on the researcher's openness to scrutinize in the woman's language, which matched the objectives of the investigation. And, then, by reflection intentionally directed to the facets that were revealed and concealed through the lines of the entity interrogated, in her being questioned, in the search for the sense asked ${ }^{(9)}$.

The imagination and the reflection thus allowed the comprehension of women that expressed the situation of pregnancy when having heart diseases. Eight units were established, showing the approximation and convergence movements of the participant's 
meanings, being these denoted in synthesis in the headings of these signification structures, also named by Heidegger as $a$ posteriori categories.

The comprehensive development of the domain of facts - the way the woman comprehended her experience and the lived motivated the vague and median comprehension to reach the previous vision. This movement sets free the horizon of the interpretative dimension of the sense of the Being, to be developed through the conquest of the conducting wire as concept of Being that reveals the previous conception ${ }^{(9)}$.

\section{The walking on the ontical-ontological bridge: historiog- raphy and historicity of respondents}

The historiography is defined based on the factual sphere, ontically measuring the who of the woman in the experience and lived of pregnancy when having heart diseases. The historicity, as way of being of the history, becomes possible object of the historiography. And since the presence exists historically and temporally, it allows the openness and apprehension of its existence ${ }^{(10)}$.

In its existence, being in the world, the being of the entity is formed by historicity as way of being and of happening. It emerges from the comprehension of facts, nevertheless point the phenomenal dimension, and is revealed as one questions the being, who provides meanings about the phenomenon situated and of interest. The historicity allows the investigator a safe walking on the ontical-ontological bridge reduced of presuppositions, since it scrutinizes the who that is showed in detriment of what is shown ${ }^{(10)}$.
Thus, it was aimed a schematic demonstration that transmitted to the visual scope the searches for respondents' clues considering two lines: data from the records of the institutions and of the initial questions of the interview of its characterization; and the movements of the being woman that experienced or that experiences the pregnancy when having heart diseases from the moment of the inherent existential and intersubjective meeting to the phenomenological interview, which can be seen through the example of one of the participants (Figure 1).

For greater comprehension, in Figure 1, the circumscription of the Health System was colored in gray, reflected as care network to the woman with high-risk pregnancy, from her reference for hospital institution until her institutional discharge. The red circle represented the woman's circumscription in the scenario of pregnancy follow-up. The dotted lines indicate possibilities for interlocution as the care network is open for the whom in detriment of the entity. The space that is interposed between the being and the system can be filled by the professional's openness.

\section{Hermeneutics as methodic possibility for emergence of phenomenical essence}

Hermeneutics, in this theoretical proposal, refers to the interpretation of a comprehension. Thus, after understanding the meanings of the experience lived, Heidegger incites to the unveiling of veiled senses through this more immediate comprehension. After reaching it, there is the concept of Being as a signifying synthesis that leads and opens possibilities to interpretation ${ }^{(9)}$.

The concept enlightens and substantiates the explanations of the obscurations contained in the vague and median comprehension culminating in a conducting wire that semantically reveals its proposition: the one of conducting the investigations to the stages of interpretative comprehension and unveiling of the phenomena, allowing the decision of "what kinds of obscuration or hindrance are possible and necessary for an explicit illumination of the meaning of Being ${ }^{\prime \prime(9)}$.

The concept of Being of women who gestated when having heart diseases was constituted as: knowing the risk and both planning as well as not knowing how to avoid it... and being surprised when discovering pregnancy; telling how they felt physically and emotionally in gestation; feeling safe by the prenatal care routine; having family members concerned with the heart problem and counting with support; having been demanded by doctors for getting pregnant; being concerned with the baby and asking the doctor to prioritize the baby in being saved; having felt fear of dying in childbirth; knowing that the cardiologist provides the opinion but the obstetrician decides the delivery method; having more will to live and take care of themselves because the problem remains the same; understanding that they have reached the limit and seeking tubal sterilization.

Figure 1 - Schematic representation of participant P12's historiography and historicity 
The Heideggerian hermeneutics is based as existential analytics of comprehension reached in the sphere of facts, the reach of truth as correspondence between the judgement and the real object. It is constituted on interpretation of facticity through unveiling concepts of ways that are possibilities of the Being, covered by the entity that is ${ }^{(9)}$. Therefore, the subjection of the Being to the authority of the paradigm of exact and natural sciences establishes an obstacle for its blossoming as subjectivity.

In fact, overlapping to the Being without its will, it seems that the conditions through which the Beingthere shall be manifested are already radically ready, veiling the possibilities of own Being. It is not for another reason that women who gestate when having heart diseases, when signifying their comprehension about the phenomena experienced, made it based on concepts and references of tradition.

In this context, women showed themselves as Being-there based on the Being that is gestating or that has this experience. Aiming at revealing the woman's existential movement, it was built, through the conducting wire, a representation of meanings unveiled in the study (Figure 2).

As ek-sistence, the woman moved herself in an impersonal, improper and inauthentic way through the publicity of the everyday life of the high-risk pregnancy. Her median comprehension was revealed in the ways of Being by idle talk, curiosity and ambiguity, proving to be disperse and impermanent, in decadency. Being-in-the-world shared and surrounded by family members, acquaintances, health professionals and by her baby, it was in the occupation and in the manuality directed to and by the instruments, being-with that is deficient and experimenting a substantive solicitude expressed by the provoking technique. She improperly distressed herself in the disposition of Being-towards-death and feared in the modes of dread, horror and terror. Through fleeting facets, she announced herself as Being-towards-possibilities to readily decline tempted, tranquil, alienated and imprisoned.

Based on the comprehension of the hermeneutic cycle, the figure also represents the idea that the parts can only be understood through the whole they form. Thus, even if there are unveiled predominant meanings of certain Units of Signification and their respective vague and median comprehensions, these also are unveiled in others, denoting the phenomenical totality.

\section{CONCLUSION}

When recomposing the investigative path of analysis of the phenomenon of gestation for women with heart diseases, it was evidenced the operationality of concepts that the investigator must appropriate to sustain the episteme produced in Martin Heidegger's theoretical and methodical framework.

It is necessary, in this plan, that the study object intended can announce the framework, and not the contrary. This implies, on the hand of that investigating, a necessary worldview that considers the subjectivities of the person in health or disease situation and that puts in position of active and attentive listening, reducing his/her presuppositions and value judgment.

In this sense, it is worth highlighting that the phenomenology is imbricated on the clinical practice of nurses and other members of the healthcare team, given that it is conceived centered in the individual's necessities. It becomes, therefore, professional contradiction the health care limited to the biological sphere, in special for that related to the woman's health.

Regarding the production of knowledge enlightened by Martin Heidegger's framework, it is denoted that, for a reach that is interdisciplinary and happens among pairs, in both national and international scenario, it must reveal epistemological rigor. Based on the latter, Nursing has been consolidating studies under this philosopher's thinking, aiming at developing research that are constructed in the perspective of unveiling of experienced and lived phenomena in the field of health and in the area of nursing.

\section{REFERENCES}

1. Sebold LF, Kempfer SS, Girondi JBR, Prado ML. Perception of nursing faculty on the care: Heidegger constructions. Rev Esc Enferm USP [Internet]. 2016 [cited 2017 Sep 25];50(n.esp):38-45. Available from: doi: http://dx.doi.org/10.1590/S0080-623420160000300006 
2. Aneas TV, Ayres JRCM. [Meanings and senses of healthcare practices: fundamental ontology and the reconstruction of healthcare]. Interface Com Saude Educ (Botucatu) [Internet]. 2011 [cited 2017 Sep 25];15(38):651-662. Available from: http://dx.doi.org/10.1590/S141432832011000300003 Portuguese.

3. Almeida IS, Crivaro ET, Salimena AMO, Souza IEO. [The getting under way of the nursing in phenomenology: re visiting the academical production]. Rev Eletr Enf [Internet]. 2009 [cited 2017 Feb 6];11(3):695-9. Available from: https://www.fen.ufg.br/revista/v11/n3/pdf/ v11n3a30.pdf Portuguese.

4. Guerrero-Castañeda RF, Prado ML, Kempfer SS, Vargas MGO. Transcendence, historicity and temporality of being elderly: nursing reflection-using Heidegger. Rev Bras Enferm [Internet]. 2017 [cited 2017 Sep 25];70(4):891-5. Available from: doi: http://dx.doi. org/10.1590/0034-7167-2016-0275

5. Amorim, TV. Gestar-sendo-portadora-de- cardiopatia: contribuições para o cuidado em Saúde da Mulher [Thesis]. Rio de Janeiro: Universidade Federal do Rio de Janeiro, Escola de Enfermagem Anna Nery; 2015.

6. Ministério da Saúde (MS), Secretaria de Atenção à Saúde, Departamento de Ações Programáticas Estratégicas. Gestação de alto risco: manual técnico. 5 ed. Brasília: Ministério da Saúde; 2012 [cited 2017 Mar 30]. 302 p. Available from: http://bvsms.saude.gov.br/bvs/ publicacoes/manual_tecnico_gestacao_alto_risco.pdf

7. Amorim TV, Souza IEO, Moura MAV, Queiroz ABA, Salimena AMO. Nursing care perspectives in high-risk pregnancy: integrative review. Enferm Glob [Internet]. 2017 [cited 2017 Sep 25];16(46):500-14. Available from: https://doi.org/10.6018/eglobal.16.2.238861

8. Giles TR. História do existencialismo e da fenomenologia. 12 ed. São Paulo: EPU; 1989. 324 p.

9. Heidegger M. Ser e tempo. 5 ed. Petrópolis (RJ):Vozes; 2011. 1200 p.

10. Amorim TV, Salimena AMO, Souza IEO. Historicidade e historiografia: contribuição da entrevista fenomenológica para a enfermagem. Cult Cuid. 2015;19(41):71-81. doi:10.14198/cuid.2015.41.09 